\title{
Estimation of genetic parameters for productive life, reproduction, and milk-production traits in US dairy goats
}

\author{
V. J. Castañeda-Bustos, ${ }^{*}$ H. H. Montaldo, $\dagger^{1}$ G. Torres-Hernández, ${ }^{\star}$ S. Pérez-Elizalde, ${ }^{\star}$ M. Valencia-Posadas,‡ \\ O. Hernández-Mendo, ${ }^{*}$ and L. Shepard§ \\ ${ }^{*}$ Colegio de Postgraduados, Campus Montecillo, Montecillo, Estado de México 56230, Mexico \\ †Departamento de Genética y Bioestadística, Facultad de Medicina Veterinaria y Zootecnia, Universidad Nacional Autónoma de México, \\ Ciudad Universitaria, DF 04510, Mexico \\ ‡División de Ciencias de la Vida, Campus Irapuato-Salamanca, Universidad de Guanajuato, Ex Hacienda El Copal, Irapuato, Guanajuato 36500, \\ Mexico \\ §American Dairy Goat Association, Spindale, NC 28160
}

\section{ABSTRACT}

Heritabilities and correlations for milk yield (MY), fat yield (FY), protein yield (PY), combined fat and protein yield (FPY), fat percentage $(\mathrm{F} \%)$, protein percentage $(\mathrm{P} \%)$, age at first kidding (AFK), interval between the first and second kidding (KI), and real and functional productive life at 72 mo (FPL72) of 33,725 US dairy goats, were estimated using animal models. Productive life was defined as the total days in production until 72 mo of age (PL72) for goats having the opportunity to express the trait. Functional productive life was obtained by correcting PL72 for MY, FY, PY, and final type score (FS). Six selection indexes were used, including or excluding PL72, with 6 groups of different economic weights, to estimate the responses to selection considering MY, FY, PY, and PL72 as selection criteria. The main criteria that determined the culling of a goat from the herd were low FS, MY, and FY per lactation. Heritability estimates were 0.22 , $0.17,0.37,0.37,0.38,0.39,0.54,0.64,0.09$, and 0.16 for PL72, FPL72, MY, FY, PY, FPY, F\%, P\%, KI, and AFK, respectively. Most genetic correlations between the evaluated traits and PL72 or FPL72 were positive, except for $\mathrm{F} \%(-0.04$ and -0.06 , respectively), $\mathrm{P} \%$ $(-0.002$ and -0.03 , respectively), and AFK $(-0.03$ and -0.01 , respectively). The highest genetic correlations were between FPL72 and MY (0.39) and between PL72 and MY (0.33). Most phenotypic correlations between the traits evaluated and FPL72 and PL72 were positive $(>0.23$ and $>0.26$, respectively), except for $\mathrm{F} \%(-0.004$ and -0.02 , respectively), $\mathrm{P} \%(-0.05$ and -0.02$)$, KI $(-0.01$ and -0.07$)$, and AFK $(-0.08$ and -0.08$)$. The direct selection for PL72 increased it by $102.28 \mathrm{~d}$ per generation. The use of MY, FY, PY, KI, or AFK as

Received September 19, 2013.

Accepted December 30, 2013.

${ }^{1}$ Corresponding author: montaldo@unam.mx selection criteria increased PL72 by $39.21,27.33,35.90$, -8.28 , or $2.77 \mathrm{~d}$ per generation, respectively. The inclusion of PL72 as selection criterion increased the expected response per generation from 0.15 to $17.35 \%$ in all selection indices studied.

Key words: productive life, heritability, genetic correlation, selection index

\section{INTRODUCTION}

Genetic evaluations for milk, fat, and protein yields in US goats have been calculated since 1983 in bucks and since 1984 in does. Genetic evaluations for these traits of US dairy goats have been calculated annually by the USDA Animal Improvement Programs Laboratory (Beltsville, MD) from records that are available through DHI programs and the American Dairy Goat Association (Spindale, NC; Wiggans and Hubbard, 2001).

For developing efficient selection programs, it is necessary to estimate genetic parameters (Weppert and Hayes, 2004). Some of the traits considered as potential selection criteria in dairy goats are milk, fat, and protein yields, type traits (Montaldo and Manfredi, 2002), reproductive traits (Torres-Vázquez et al., 2009; Montaldo et al., 2010), and longevity (Pérez-Razo et al., 2004). Longevity, despite being a little-studied trait not used so far in the genetic evaluation of goats, is of great economic importance, as it combines many traits associated with the permanence of an animal in the herd (Tsuruta et al., 2005). The increase in longevity allows a reduction in the number of replacement animals (Sewalem et al., 2007). It also allows a reduction in health care costs, especially those caused by mastitis (Rogers et al., 1998; Jensen et al., 1999), and an increase in the total milk production of the herd by increasing the proportion of mature animals with a greater production per lactation (Vollema et al., 2000).

Several definitions of longevity or productive life (PL) exist. Real PL is described in various ways, such 
as number of days from first calving to death or culling (VanRaden et al., 2006; Sewalem et al., 2007), total days in production (VanRaden and Klaaskate, 1993), stayability at different ages (Jakobsen et al., 2010) or at a specific number of calvings (Martinez et al., 2004), total months in production until a certain age (VanRaden et al., 2006), and number of lactations recorded (PérezCabal et al., 2006). Functional PL (FPL) is defined as the ability to avoid involuntary culling caused by health or reproductive problems, and is obtained by including some covariates potentially used as voluntary culling criteria (e.g., milk, fat, and protein first-lactation production, and type traits) in the statistical models used to analyze PL (Dekkers, 1993; Mark, 2004).

Direct selection for longevity in the species used for milk production is not feasible, mainly because to obtain the information, the animal should be able to reach an advanced age or die, which would mean waiting too long and not being able to keep a herd with an age structure suitable for production or for selecting replacements. Trying to address this situation, several studies on cattle have been carried out to obtain early measures related to longevity, such as type traits (Martinez et al., 2004), functional traits, and milk-production traits (Tsuruta et al., 2005). Some of the countries that have used early measures as indirect predictors of longevity in cows are the United States (Short and Lawlor, 1992; Cruickshank et al., 2002), Canada (Sewalem et al., 2004, 2007), Japan (Hagiya et al., 2005), and Spain (Pérez et al., 1999).

Information about genetic parameters for longevity in goats and its relationship with milk production, reproductive, or conformation traits are scarce and limited to stayability estimates at a certain age or number of kiddings as a measure of PL (Pérez-Razo et al., 2004; Vicencio, 2009; Valencia-Posadas et al., 2010). Stayability merely indicates the presence or absence of the goat at a fixed age; therefore, it does not provide detailed quantitative information of the time during which a goat was productive. Thus, the aim of this study was to estimate the heritabilities and the genetic and phenotypic correlations between real PL and FPL at $72 \mathrm{mo}$, and milk-production and reproductive traits, using a quantitative definition of PL.

\section{MATERIALS AND METHODS}

\section{Data}

This study used data from the American Dairy Goat Association, processed by the USDA Animal Improvement Programs Laboratory, which contained information about milk (MY), fat (FY), and protein (PY) yields of Alpine, La Mancha, Nubian, Saanen, and
Toggenburg breeds. Yields were corrected to $305 \mathrm{~d}$ and mature equivalents. The records also included fat percentage $(\mathbf{F} \%)$; protein percentage $(\mathbf{P} \%)$; information of the sire, herd, birth, and kidding dates; and DIM production (15 to $305 \mathrm{~d}$ ).

To estimate the parameters more precisely, we only used records from goats with consecutive information for $\geq 1$ lactation, with a maximum of 10 lactations, and which remained in the same herd in all lactations. Records with information errors about date of birth and date of kidding were eliminated; herds with $<5$ observations or $<2$ breeds were also eliminated. The records containing information on FY but not on PY, or vice versa, were considered as missing observations. The final data file contained information on MY, FY, and PY of the first lactation for 33,725 goats born from 9,716 sires and 24,474 dams. Data of individuals without breed or identification information were eliminated from the original pedigree data set. The pedigree was subsequently ordered generationally and recoded using the software Pedigree Viewer 6.3 (Kinghorn and Kinghorn, 2009); the final file contained the complete information of 209,530 individuals from the breeds analyzed.

We calculated the age of the animals as the difference between the last date of kidding and the date of birth plus the last days in production recorded; we also calculated the age at first kidding (AFK), the interval between the first and second kidding (KI), and the PL at 48, 60, and 72 mo (PL48, PL60, and PL72, respectively), using the same criteria used for the genetic evaluation of longevity in dairy cows in the United States (VanRaden and Klaaskate, 1993); PL was obtained using information from the first to the tenth lactation. Records with KI $<168$ or $>885$ d (236 animals), and AFK $<271$ or $>1,140 \mathrm{~d}$ (479 animals) were considered missing.

Productive life was defined as the total number of days in production recorded (VanRaden and Klaaskate, 1993 ) until the goat was 48,60 , and 72 mo of age. If the goat did not stay in the herd or did not have the opportunity to complete each period, data was considered as censored and was not included in the analysis. To obtain PL, we first determined if the animal had the opportunity to stay in the herd at 3 different ages (48, 60 , and $72 \mathrm{mo}$ ), depending on the period of recording of the herd to which it belonged. This was calculated as last registration of the herd - date of birth $\geq 48,60$, or 72 mo.

If the goat did not have the opportunity to stay in the herd at 48,60 , or $72 \mathrm{mo}$, the PL was defined as a missing value and was not included in the file for analysis. If the goat had the opportunity to stay in the herd, its PL was the sum of the DIM production 
recorded (with a maximum of $305 \mathrm{~d}$ per lactation) until the corresponding age $(48,60$, or $72 \mathrm{mo})$. Functional productive life at 48, 60, and 72 mo (FPL72) was PL corrected for milk-production traits (MY, FY, and PY) and final type score (FS).

In this study, we analyzed 10 traits: MY, FY, PY, combined fat and protein yield (FPY), F\%, P\%, KI, AFK, PL72, and FPL72.

\section{Model}

Four kidding seasons (KS) were defined: January to February $(\mathrm{n}=10,403)$, March $(\mathrm{n}=9,308)$, April $(\mathrm{n}=$ 9,569), and May to December ( $\mathrm{n}=11,273)$; and 4 birth seasons (BS): March $(\mathrm{n}=11,272)$, April $(\mathrm{n}=12,090)$, May to July ( $\mathrm{n}=8,096)$, and August to February (n $=9,095$ ), to find a balance in the number of observations, given that, due to the reproductive seasonality of this species, kiddings and births were concentrated in certain months of the year, and due to distributions of kiddings and births being different, grouping of months for kidding season and birth season were very different between them. Twenty levels of BS-breed (BSB) and KS-breed (KSB) were obtained by combining KS or BS with breed (Alpine, La Mancha, Nubian, Saanen, and Toggenburg).

The traits were initially analyzed with single-trait animal models to estimate the phenotypic, additive genetic, and residual variances, using ASReml 3.0 software (Gilmour et al., 2009). The matrix representation of the model (Mrode, 2005) is

$$
\mathbf{y}=\mathbf{X b}+\mathbf{Z u}+\mathbf{e}
$$

where $\mathbf{y}$ is the vector of observations of the traits studied; $\mathbf{X}$ is the incidence matrix of fixed effects for $\mathrm{KSB}$ or $\mathrm{BSB}$; $\mathbf{b}$ is the vector of fixed effects of KSB or $\mathrm{BSB} ; \mathbf{Z}$ is the incidence matrix of the random effects of additive genetic effects of the animal, herd-year of kidding-breed (HYKB), or herd-year of birth-breed (HYBB) effects, and herd-sire (HS) effect; $\mathbf{u}$ is the vector of random effects of the additive genetic effects of the animal, HYKB, or HYBB and HS; and $\mathbf{e}$ is the vector of random error. Convergence of the analyses was assumed when the change in the restricted likelihood function was less than 0.002 and the change in the parameter estimates was less than 1\% (Gilmour et al., 2009).

Considering that when the group subclass sizes are small, as in the current case, much information can be lost and, as a result, the compromise between accounting for bias and reducing prediction error variances should be found (Van Bebber et al., 1997). The HYKB and HYBB effects were considered as random to avoid these losses (Chauhan, 1987). In the model used to obtain the genetic parameters for production traits (MY, FY, PY, FPY, F\%, and P\%) and KI, the effects considered were HYKB as random and KSB as fixed, whereas HYBB and BSB were fitted as random and fixed effect, respectively, for the AFK and PL. The effect of KSB was considered for production traits and $\mathrm{KI}$ because KS and breed modifies these traits, whereas BS and breed modifies AFK and PL. In the final data file $(\mathrm{n}=33,725)$, only the levels with $\geq 5$ observations for HYBB and HYKB were included, leaving, at the end of the edition, 3,255 and 1,809 levels, respectively. The random effect of HS was included in the models for all the traits analyzed.

Milk-production traits (MY, FY, and PY) and FS were included as covariates in the analysis models (Sewalem et al., 2004) to obtain estimates of genetic parameters of FPL at 48, 60, or $72 \mathrm{mo}$, and were excluded in the analysis models for PL48, PL60, and PL72. Regression coefficients for MY, PY, PY, and FS were obtained to know which factors were important for culling decisions in goats.

\section{Genetic Parameters}

Variance components and heritability were obtained using a single-trait animal model, whereas genetic $\left(\mathbf{r}_{\mathrm{g}}\right)$ and phenotypic $\left(\mathbf{r}_{\mathrm{p}}\right)$ correlations were obtained using bivariate analyses.

Heritability. For calculating the heritability within herd-breed, the total variance and the phenotypic variance were estimated as follows:

Total variance:

$$
\hat{\sigma}_{\mathrm{t}}^{2}=\hat{\sigma}_{\mathrm{a}}^{2}+\hat{\sigma}_{\mathrm{HYB}}^{2}+\hat{\sigma}_{\mathrm{HS}}^{2}+\hat{\sigma}_{\mathrm{e}}^{2},
$$

where $\hat{\sigma}_{\mathrm{t}}^{2}=$ estimated total variance; $\hat{\sigma}_{\mathrm{a}}^{2}=$ estimated additive genetic variance of the animal; $\hat{\sigma}_{\mathrm{HYB}}^{2}=$ estimated HYKB or HYBB variance, according to the trait; $\hat{\sigma}_{\mathrm{HS}}^{2}=$ estimated variance of the HS effect; and $\hat{\sigma}_{\mathrm{e}}^{2}$ $=$ estimated error variance.

Phenotypic variance:

$$
\hat{\sigma}_{\mathrm{p}}^{2}=\hat{\sigma}_{\mathrm{a}}^{2}+\hat{\sigma}_{\mathrm{HS}}^{2}+\hat{\sigma}_{\mathrm{e}}^{2},
$$

where $\hat{\sigma}_{\mathrm{p}}^{2}=$ estimated phenotypic variance.

Having determined the variances (total and phenotypic), the heritability $\left(\hat{\mathrm{h}}^{2}\right)$ was estimated as follows:

$$
\hat{\mathrm{h}}^{2}=\frac{\hat{\sigma}_{\mathrm{a}}^{2}}{\hat{\sigma}_{\mathrm{p}}^{2}} \text {. }
$$

The ratio of $\hat{\sigma}_{\mathrm{HYB}}^{2}$ with respect to $\hat{\sigma}_{\mathrm{t}}^{2}$ (herd-year-breed ratio, HYBR) was calculated as follows: 


$$
\mathrm{HYBR}=\frac{\hat{\sigma}_{\mathrm{HYB}}^{2}}{\hat{\sigma}_{\mathrm{t}}^{2}},
$$

using variances obtained with a single-trait animal model to estimate the contribution of this effect. To estimate the contribution of the HS effect, we calculated the ratio of $\hat{\sigma}_{\mathrm{HS}}^{2}$ with respect to $\hat{\sigma}_{\mathrm{t}}^{2}$ (herd-sire ratio, HSR):

$$
\mathrm{HSR}=\frac{\hat{\sigma}_{\mathrm{HS}}^{2}}{\hat{\sigma}_{\mathrm{t}}^{2}},
$$

using variances obtained using a single-trait animal model.

Genetic and Phenotypic Correlations. The bivariate analyses used to obtain $\mathrm{r}_{\mathrm{g}}$ and $\mathrm{r}_{\mathrm{p}}$ (Mrode, 2005) included the same effects included in the univariate models mentioned above. The analysis was performed using the software ASReml 3.0 (Gilmour et al., 2009). To test whether $r_{g}$ and $r_{p}$ were different from zero, we estimated their confidence intervals with a significance level of $95 \%$ using the software package for $\mathrm{R}$ psychometric (Fletcher, 2010).

\section{Response to Selection}

To estimate the responses to selection considering MY, FY, PY, and PL72 as selection criteria, we used 6 selection indices that included or excluded PL72. For the selection, we evaluated 6 groups with different relative economic weight. The economic weights for MY, FY, and PY were $0.01,1.15$, and 2.55, respectively (Wiggans and Hubbard, 2001), and remained the same in the 6 indices, whereas PL was assigned a different economic weight in each index $(0.01,0.03,0.05,0.07$, 0.09 , and 0.1 ), derived from the ratio of PL with respect to PY (0.02) used in cattle (Cole and VanRaden, 2010), to explore a range of values that could probably cover a relative value appropriate for goats. The responses to selection per generation were obtained from the average of the results of the expected responses per generation in the selection indices for females and males, and assuming a selection intensity of 1 .

In the case of the selection of females, it was assumed that a record existed for each one and 20 records of half-sisters. For males, 20 records of half-sisters and 10 records of daughters were assumed. In addition, it was assumed that 1 record of the dam existed for both sexes. The expected response to selection for each index was estimated using MTINDEX software (Van der Werf, 2007).

\section{RESULTS}

The descriptive statistics for the traits evaluated (PL72, MY, FY, PY, FPY, F\%, P\%, KI, and AFK) are shown in Table 1. The PL72 ranged from 32 to 1,560 $\mathrm{d}$, with an average of $579.4 \mathrm{~d}$. The averages (SD within parentheses) for milk-production traits were 1,043.1 (336.36), 37.1 (10.84), 30.5 (7.59), and $67.6 \mathrm{~kg}(17.70$ $\mathrm{kg})$. The averages for $\mathrm{F} \%$ and $\mathrm{P} \%$ were $3.8(0.87)$ and $3.1 \%(0.47 \%)$, respectively.

With respect to the reproductive traits evaluated, the average (SD in parentheses) KI was $387.3 \mathrm{~d}$ (101.52 d) and the average AFK was $507.97 \mathrm{~d}(153.50 \mathrm{~d})$. In the analysis model for FPL72, all regression coefficients of MY, PY, FY, and FS on PL72 were positive (66.12 $\pm 3.48,3.40 \pm 6.61,20.44 \pm 6.49$, and $3.06 \pm 0.07$, respectively), and most of the covariates included (MY, $\mathrm{FY}$, and FS) were significant $(P<0.01)$, except for PY $(P=0.60)$, showing that the probability that a goat is voluntarily culled from a herd increases when its MY, $\mathrm{FY}$, or FS are low.

\section{Genetic Parameters}

The variances (total, phenotypic, and additive genetic), HYBR, HSR, and the estimates of heritability for the evaluated traits are shown in Table 2. The estimates of heritability were $0.22 \pm 0.01$ and $0.17 \pm 0.01$ for PL72 and FPL72, respectively. Milk-production and -composition traits had estimates of heritability of 0.37 ,

Table 1. Descriptive statistics for the traits analyzed in US goats

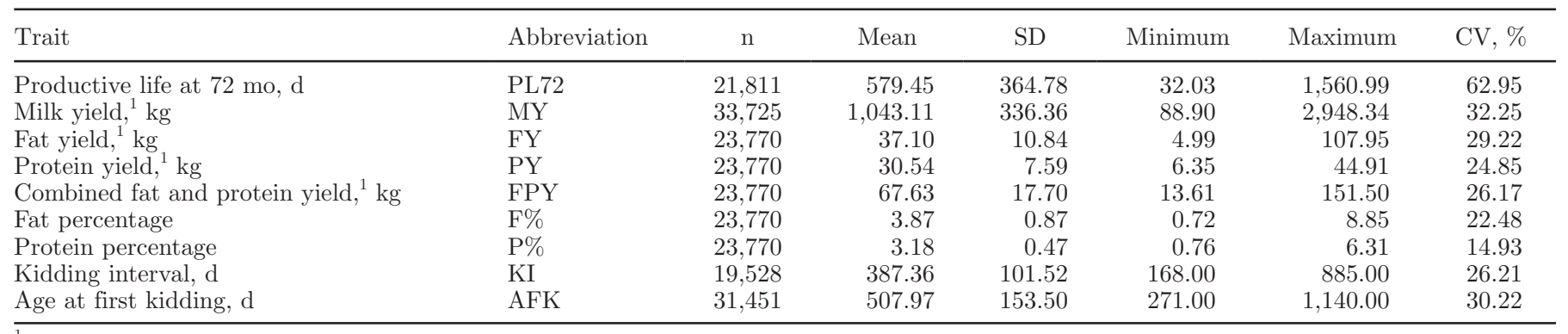

${ }^{1}$ Yields corrected to $305 \mathrm{~d}$ and mature equivalent. 
$0.37,0.38,0.39,0.54$, and 0.64 for MY, FY, PY, FPY, $\mathrm{F} \%$, and $\mathrm{P} \%$, respectively. The estimates of heritability for KI and AFK were $0.09 \pm 0.02$ and $0.16 \pm 0.01$, respectively. The highest variances of HSR with respect to total variance was for AFK (0.10). The variances of HSR were 0.04 for PL72, MY, PY, FPY, and F\%, 0.05 for FPL72 and FY, 0.01 for P\% and KI, and 0.10 for AFK. The highest variances of HYBR were for PY and FPY (0.44) and represented ratios, with respect to the total variance, of $0.07,0.14,0.40,0.37,0.44,0.44,0.29$, $0.19,0.15$, and 0.35 for PL72, FPL72, MY, FY, PY, FPY, F\%, P\%, KI, and AFK, respectively.

\section{Genetic and Phenotypic Correlations}

Preliminary analyses showed that PL72 had high $\mathrm{r}_{\mathrm{g}}$, with PL48 (0.96 \pm 0.007$)$ and PL60 (0.99 \pm 0.001$)$, indicating that similar results would be obtained with any of them from the viewpoint of selection. Considering that, by definition, PL72 is calculated at a higher age, it might better reflect the longevity of the goats, plus PL72 had higher heritability than PL48 and PL60 (0.22 compared with a value of 0.17 for PL48 and PL60), which is why, in this study, we decided to use only PL72. The $r_{g}$ and $r_{p}$ estimated between PL (PL72 and FPL72) and the reproductive and milk-production traits are shown in Table 3.

The $\mathrm{r}_{\mathrm{g}}$ between PL72 and the milk-production and -composition traits were $0.33,0.23,0.30,0.27,-0.04$, and -0.002 for MY, FY, PY, FPY, F\%, and P\%, respectively. The $\mathrm{r}_{\mathrm{g}}$ between KI and PL72 was 0.11, and -0.03 between PL72 and AFK. The $r_{g}$ between PL72 and production traits (MY, FY, PY, and FPY) and between PL72 and KI were significant $(P<0.05)$; similarly, the $\mathrm{r}_{\mathrm{g}}$ between PL72 and F\% and AFK were significant $(P<0.05)$, although, similar to the $\mathrm{r}_{\mathrm{g}}$ between PL72 and P\%, they were close to zero.

The $\mathrm{r}_{\mathrm{p}}$ between milk-production traits and PL72 were $0.25,0.23,0.25$, and 0.25 for MY, FY, PY, and FPY, respectively, and, similar to the $r_{g}$, all these $r_{p}$ were significant $(P<0.05)$. The $\mathrm{r}_{\mathrm{p}}$ between PL72 and $\mathrm{F} \%$ and $\mathrm{P} \%$ were -0.004 and -0.05 , respectively, whereas the $r_{p}$ between PL72 and KI and AFK were -0.01 and -0.08 , respectively. Out of these, only the $r_{p}$ between PL72 and $\mathrm{P} \%$ and AFK were significant $(P<0.05)$.

The $r_{g}$ between FPL72 and MY, FY, PY, and FPY were $0.39,0.26,0.29$, and 0.28 , respectively. The $r_{g}$ of the milk-production traits with FPL72, similar to the $\mathrm{r}_{\mathrm{g}}$ between KI and FPL72 (0.05), were all positive and significant $(P<0.05)$. On the other hand, the $\mathrm{r}_{\mathrm{g}}$ between FPL72 and F\%, P\%, and AFK were negative and close to zero $(-0.06,-0.03$, and -0.01 , respectively), but significant $(P<0.05)$, except for the $\mathrm{r}_{\mathrm{g}}$ between FPL72 and AFK.

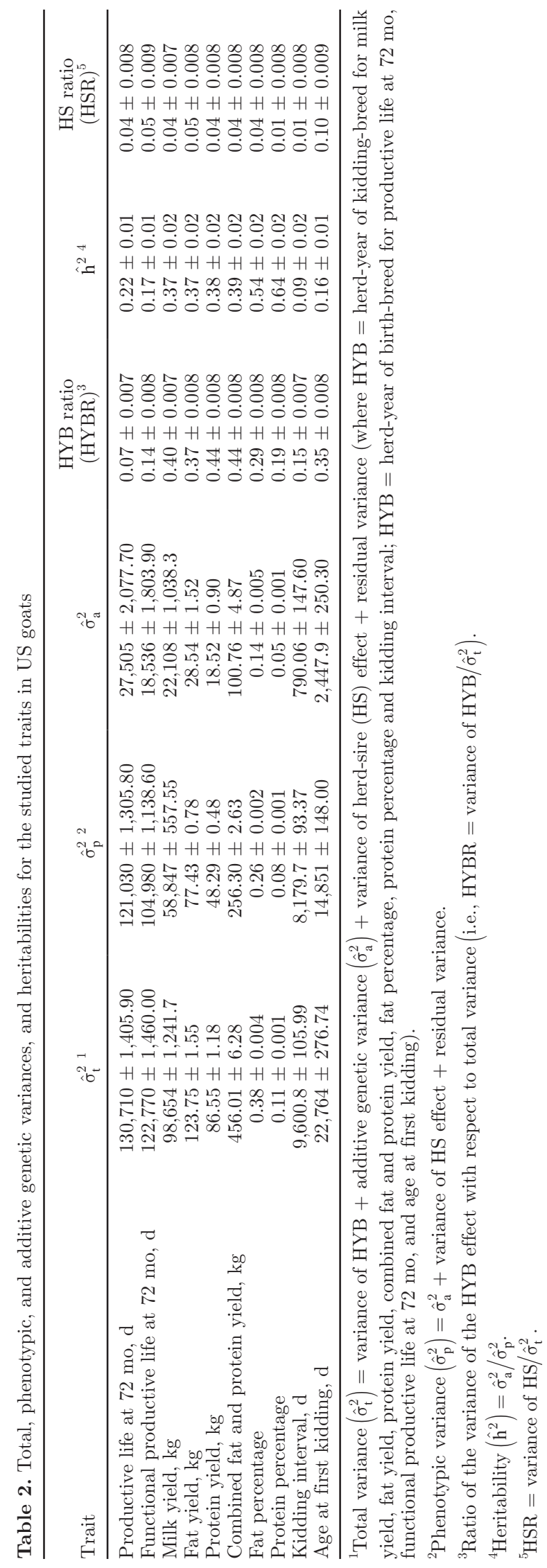


Table 3. Genetic and phenotypic correlations $( \pm \mathrm{SE})$ between production and reproductive traits with productive life and functional productive life at 72 mo in US goats

\begin{tabular}{|c|c|c|c|c|}
\hline \multirow[b]{2}{*}{ Trait $^{1}$} & \multicolumn{2}{|c|}{ Genetic correlation } & \multicolumn{2}{|c|}{ Phenotypic correlation } \\
\hline & $\mathrm{PL} 72^{2}$ & FPL72 $2^{3}$ & PL72 & FPL72 \\
\hline MY & $0.33 \pm 0.04$ & $0.39 \pm 0.04$ & $0.25 \pm 0.008$ & $0.29 \pm 0.009$ \\
\hline FY & $0.23 \pm 0.05$ & $0.26 \pm 0.05$ & $0.23 \pm 0.009$ & $0.26 \pm 0.01$ \\
\hline PY & $0.30 \pm 0.05$ & $0.29 \pm 0.06$ & $0.25 \pm 0.009$ & $0.29 \pm 0.01$ \\
\hline FPY & $0.27 \pm 0.05$ & $0.28 \pm 0.05$ & $0.25 \pm 0.009$ & $0.29 \pm 0.01$ \\
\hline $\mathrm{F} \%$ & $-0.04 \pm 0.04$ & $-0.06 \pm 0.05$ & $-0.004 \pm 0.01$ & $-0.02 \pm 0.01$ \\
\hline $\mathrm{P} \%$ & $-0.002 \pm 0.04$ & $-0.03 \pm 0.04$ & $-0.05 \pm 0.01$ & $-0.02 \pm 0.01$ \\
\hline KI & $0.11 \pm 0.08$ & $0.05 \pm 0.09$ & $-0.01 \pm 0.01$ & $-0.07 \pm 0.01$ \\
\hline AFK & $-0.03 \pm 0.06$ & $-0.01 \pm 0.07$ & $-0.08 \pm 0.008$ & $-0.08 \pm 0.009$ \\
\hline
\end{tabular}

${ }^{1} \mathrm{MY}=$ milk yield; $\mathrm{FY}=$ fat yield; $\mathrm{PY}=$ protein yield; $\mathrm{FPY}=$ combined fat and protein yield; $\mathrm{F} \%=$ fat percentage; $\mathrm{P} \%=$ protein percentage; $\mathrm{KI}=$ kidding interval; $\mathrm{AFK}=$ age at first kidding.

${ }^{2} \mathrm{PL} 72=$ productive life at $72 \mathrm{mo}$.

${ }^{3} \mathrm{FPL} 72=$ functional productive life at $72 \mathrm{mo}$.

As in the case of PL72, both the $r_{g}$ and the $r_{p}$ between the milk-production traits and FPL72 were all positive and significant $(P<0.05)$, with slightly higher values than those found in the $r_{p}$ between the same traits and PL72. The $r_{p}$ obtained were $0.29,0.26,0.29$, and 0.29 between FPL72 and MY, FY, PY, and FPY, respectively. The $r_{p}$ between FPL72 and milk components $(\mathrm{F} \%$ and $\mathrm{P} \%)$ were -0.02 in both cases and were not significant, whereas the $\mathrm{r}_{\mathrm{p}}$ between KI and FPL72 $(-0.07)$ and between AFK and FPL72 (-0.08) were significant $(P<0.05)$ in both cases (Table 3$)$.

\section{Response to Selection}

The increase in PL72 per generation, selecting directly for this trait, was $102.28 \mathrm{~d}$ (Table 4), considering this value as $100 \%$ of the increase in PL72 by selection; the selection for the increase in MY, FY, PY, KI, or AFK achieved an increase in PL72 per generation of $39.21 \mathrm{~d}(38.33 \%), 27.33 \mathrm{~d}$ (26.72\%), $35.90 \mathrm{~d}(35.10 \%)$,
$-8.28 \mathrm{~d}(-8.10 \%)$, or $2.77 \mathrm{~d}(2.70 \%)$, respectively. The inclusion of PL72 as a selection criterion increased from 0.15 to $17.35 \%$ the expected response per generation in all selection indices studied (Table 5).

\section{DISCUSSION}

During the life of a goat and other species (i.e., dairy cows), the risk always exists that the animal is rejected for not meeting the requirements of the herd to which it belongs. According to the regression coefficients obtained from the model for the analysis of FPL72 (66.12 $\pm 3.48,20.44 \pm 6.49$, and $3.06 \pm 0.07$ for MY, FY, and FS, respectively), if a goat has higher MY, FY, and FS, it will be at less risk of being culled from the herd. The importance of PY as culling criterion in cows (Sewalem et al., 2004) was not evident in this study, probably because, having a high correlation with MY (>0.90; Torres-Vázquez et al., 2009), it provides similar information in the model.

Table 4. Responses to selection for productive life at 72 mo in US goats

\begin{tabular}{|c|c|c|c|c|}
\hline \multirow[b]{2}{*}{ Selection type } & \multicolumn{3}{|c|}{ Response to selection per generation, ${ }^{1} \mathrm{~d}$} & \multirow{2}{*}{$\begin{array}{c}\text { Increase in } \\
\text { productive life, }{ }^{2} \%\end{array}$} \\
\hline & Females & Males & Total $^{3}$ & \\
\hline Direct & 95.19 & 109.37 & 102.28 & 100 \\
\hline \multicolumn{5}{|l|}{ Indirect $^{4}$} \\
\hline MY & 37.47 & 40.95 & 39.21 & 38.33 \\
\hline FY & 26.12 & 28.54 & 27.33 & 26.72 \\
\hline PY & 34.37 & 37.44 & 35.90 & 35.10 \\
\hline KI & -7.50 & -9.07 & -8.28 & -8.10 \\
\hline AFK & 2.55 & 2.99 & 2.77 & 2.70 \\
\hline \multicolumn{5}{|c|}{$\begin{array}{l}{ }^{1} \text { Assuming } 1 \text { record for each goat, } 1 \text { record of the dam, and } 20 \text { records of half-sisters for selection of females; } \\
\text { and } 1 \text { record of the dam, } 20 \text { records of half-sisters, and } 10 \text { records of daughters for the selection of males. } \\
{ }^{2} \text { Considering direct selection as } 100 \% \text { of the response to selection. } \\
{ }^{3} \text { Average response to selection of both sexes, assuming selection intensity }=1 \text {. } \\
{ }^{4} \text { Selecting to increase milk yield (MY), fat yield (FY), or protein yield (PY), or to decrease age at first kidding } \\
\text { (AFK) or kidding interval (KI). }\end{array}$} \\
\hline
\end{tabular}


Table 5. Expected economic selection response ${ }^{1}$ for some of the traits evaluated using different economic weights for real productive life in US goats

\begin{tabular}{|c|c|c|c|c|c|}
\hline \multirow[b]{2}{*}{$\mathrm{W}_{\mathrm{PL}}{ }^{2}$} & \multirow{2}{*}{$\begin{array}{l}\text { Selection } \\
\text { criterion }^{3}\end{array}$} & \multicolumn{3}{|c|}{ Selection response per generation, $\$$} & \multirow{2}{*}{$\begin{array}{l}\text { Increase in selection } \\
\text { response, }{ }^{4} \%\end{array}$} \\
\hline & & Females ${ }^{5}$ & Males $^{6}$ & Total $^{7}$ & \\
\hline \multirow[t]{2}{*}{0.01} & With PL & 12.62 & 13.79 & 13.20 & \multirow{2}{*}{0.15} \\
\hline & Without PL & 12.60 & 13.76 & 13.18 & \\
\hline \multirow[t]{2}{*}{0.03} & With PL & 13.49 & 14.78 & 14.13 & \multirow{2}{*}{1.80} \\
\hline & Without PL & 13.27 & 14.49 & 13.88 & \\
\hline \multirow[t]{2}{*}{$0.05^{8}$} & With PL & 14.57 & 16.02 & 15.29 & \multirow{2}{*}{4.80} \\
\hline & Without PL & 13.95 & 15.24 & 14.59 & \\
\hline \multirow[t]{2}{*}{0.07} & With PL & 15.81 & 17.45 & 16.63 & \multirow{2}{*}{8.62} \\
\hline & Without PL & 14.63 & 15.99 & 15.31 & \\
\hline \multirow[t]{2}{*}{0.09} & With PL & 17.18 & 19.02 & 18.10 & \multirow{2}{*}{12.84} \\
\hline & Without PL & 15.33 & 16.75 & 16.04 & \\
\hline \multirow[t]{2}{*}{0.11} & With PL & 18.65 & 20.71 & 19.68 & \multirow{2}{*}{17.35} \\
\hline & Without PL & 16.03 & 17.52 & 16.77 & \\
\hline
\end{tabular}

${ }^{1}$ Response to selection for relative economic weights of milk yield, fat yield, protein yield, and productive life $(\mathrm{PL})$ at $72 \mathrm{mo}$ of $0.01,1.15,2.55$, and weighted $\mathrm{PL}\left(\mathrm{W}_{\mathrm{PL}}\right)$, respectively.

${ }^{2}$ Relative economic weights assigned to PL in the selection index.

${ }^{3}$ Using or without using records for PL in the selection of females and males.

${ }^{4}$ Percentage increase in the response due to PL information in the selection index.

${ }^{5}$ Assuming 1 record of each animal, 1 record of the dam, and 20 records of half-sisters.

${ }^{6}$ Assuming 1 record of the dam, 20 records of half-sisters, and 10 records of daughters.

${ }^{7}$ Average genetic gain of both sexes (monetary units), assuming selection intensity $=1$.

${ }^{8}$ Basal economic weight (Cole and VanRaden, 2010).

The averages of MY, FY, PY, and FPY, and their components ( $\mathrm{F} \%$ and $\mathrm{P} \%$ ) were within the range of values obtained in the same population (García-Peniche et al., 2012) and in Saanen goats in Mexico (TorresVázquez et al., 2009) for MY (1,026 to 1,095 kg), FY (33.5 to $38 \mathrm{~kg}$ ), PY (28.05 to $32 \mathrm{~kg}$ ), FPY (62.5 to $70 \mathrm{~kg}$ ), $\mathrm{F} \%$ (3.24 to $3.70 \%$ ), and $\mathrm{P} \%$ (2.72 to $3.10 \%$ ). However, they were higher than those found by other authors for MY (683 to $1,008 \mathrm{~kg}$ ), FY (24.05 to 30 $\mathrm{kg}$ ), PY (25.3 to $30.75 \mathrm{~kg}$ ), F\% (3.16 to $3.52 \%$ ), and P\% (2.65 to 3.07\%) in Alpine, Saanen, and Toggenburg goats in Mexico (Valencia Posadas et al., 2007a) and France (Rupp et al., 2011).

The KI average (387 d) was similar to that obtained in Alpine (384 d; García-Peniche et al., 2012), La Mancha, Nubian, Saanen, Toggenburg (379 d; Montaldo et al. 2010), and Oberhasli (369 d; García-Peniche et al., 2012) goats from the same population, but higher than the one obtained in Toggenburg goats raised in small production systems (287.91 d; Ahuya et al. 2009), and in Taggar (242.60 to 288.94 d; Bushara et al., 2010), Beetal, Beetal $\times$ Alpine, Beetal $\times$ Saanen (300-323 d; Shrestha and Fahmy, 2007), and Norwegian (367.4 d; Bagnicka et al., 2007) goats in countries such as Kenya, Sudan, Norway, and India.

The average AFK (507.97 d) coincided with that obtained in similar breeds (505.99 to 507 d; TorresVázquez et al., 2009; García-Peniche et al., 2012) and in Alpine $\times$ Beetal goats (495 d; Shrestha and Fahmy, 2007). Moreover, the average AFK found in the current study was higher than the one mentioned for Norwegian goats (412.9 d; Bagnicka et al., 2007) and lower than that for Toggenburg goats $(759.37 \mathrm{~d}$; Ahuya et al. 2009).

The differences between the means obtained in the present study with respect to higher or lower means obtained by other authors for KI and AFK, are mainly attributed to differences in reproductive seasonality between the breeds and regions of the world (Montaldo et al., 2010) as well as to differences in management.

\section{Genetic Parameters}

Great variability exists in the literature with respect to the estimates of heritability of milk-production traits in goats (MY, FY, PY, and FPY), their components $(\mathrm{F} \%$ and $\mathrm{P} \%)$ and their reproductive traits (KI and AFK) due to estimation errors associated with the sample size, structure of the data, breed used, management conditions, and estimation methodology used (Moioli et al., 2007). In addition, it was observed in the present study that the HSR contributes significantly to the total variance of AFK, whereas HYBR makes a large contribution in the total variance of most of the traits evaluated; the largest contributions of HYBR were observed in the total variance of MY, FY, PY, FPY, and AFK, which is why both HYBR and HSR must be considered in the statistical models for estimating heritability. 
Estimates of heritability for MY, FY, PY, and FPY $(0.37 \pm 0.02,0.37 \pm 0.02,0.38 \pm 0.02$, and $0.39 \pm 0.02$, respectively) were within the range of the estimated values in other populations of dairy goats for MY (0.17 to 0.41; Valencia et al., 2007; Torres-Vázquez et al., 2009; Montaldo et al., 2010) and FY (0.19 to 0.40; Barillet, 2007; Leboeuf et al., 2008; Torres-Vázquez et al., 2009) as well as for PY (0.04 to 0.37) and FPY (0.16 to 0.36 ) in other populations (Valencia Posadas et al., 2007b) or in the same population (Torrero, 2010; García-Peniche et al., 2012) of dairy goats. Similarly, estimates of heritability for $\mathrm{F} \%(0.54 \pm 0.02)$ and $\mathrm{P} \%$ $(0.64 \pm 0.02)$ were within the estimates for $\mathrm{F} \%$ (0.26 to 0.62; Valencia Posadas et al., 2007b; Rupp et al., 2011) and P\% (0.14 to 0.67; Moioli et al., 2007; Rupp et al., 2011) in other populations of dairy goats. The estimates of heritability obtained in the current study confirm the feasibility of improving the MY, FY, PY, FPY, F\%, and $\mathrm{P} \%$ of dairy goats by selection (Montaldo et al., 2010; García-Peniche et al., 2012).

The estimated heritability for KI $(0.09 \pm 0.02)$ was within the range of estimates of heritability for the same population of dairy goats $(0$ to $0.15 \pm 0.006$ to 0.09; Montaldo et al., 2010; García-Peniche et al., 2012). The estimated heritability of AFK (0.16 \pm 0.01$)$ was below the estimates in the same population $(0.23 \pm$ 0.01; García-Peniche et al., 2012) and in another dairy goat population $(0.31 \pm 0.09$; Torres-Vázquez et al. 2009). Probably, the difference is due to the inclusion of the HS effect in the analysis models. Despite this, the heritability estimate obtained for AFK confirms that selection is a viable option for modifying this trait in dairy goats.

Compared with other species, the longevity of goats is a trait that is not commonly evaluated, which limits the information about PL to a single study by Torrero (2010) in goats of the same population. That study obtained a lower heritability estimate for stayability until the second lactation $(0.13 \pm 0.01)$ than the one obtained in the present study for PL72 $(0.22 \pm 0.01)$, and although the measurements used to describe the PL life in both studies are different, both estimates of heritability can be used as future references in the development of new selection indices for increasing the longevity of goats.

The estimated heritability for PL72 was also higher than the estimates for dairy cows, using the same definition of PL as in the present study (0.08; VanRaden and Klaaskate, 1993; USDA, 2007), or using other definitions of PL, such as time from first calving to culling (0.10 to 0.18; Caraviello et al., 2004; Tsuruta et al., $2005)$, stayability at different ages $(0.001$ to $0.15 \pm 0.01$ to 0.03; Martinez et al., 2004; Valencia Posadas et al., 2008), months in production until a certain age (0.01 to
0.07; VanRaden et al., 2006), and number of recorded lactations (0.10 \pm 0.007; Pérez-Cabal et al., 2006). Similarly, the estimates of heritability for longevity found in other species were lower, as in the case of the estimates for longevity in sows (0.05 to 0.10; Serenius and Stalder, 2004; Fernández de Sevilla et al., 2008), and rabbits (0.15; Piles et al., 2006), and the estimates for longevity (0.02 to $0.06 \pm 0.01$ to 0.02 ; El-Saied et al., 2005) or stayability at different ages ( 0 to $0.13 \pm$ 0.05; Hatcher et al., 2010) in sheep.

The estimated heritability of FPL72 obtained in this study $(0.17 \pm 0.01)$ was higher than what was estimated in sheep, for which FPL was defined as the months elapsed from one lactation to the next or to culling, corrected for milk production $(0.11 \pm 0.025$; Riggio et al., 2009); it was slightly higher than the upper limit of the range obtained in dairy cows $(0.06$ to 0.14$)$, for which FPL was defined as the days after the first calving to culling (0.06 to $0.14 \pm 0.01$; Sewalem et al., 2005; Samoré et al., 2010), or the number of lactations (0.10; Pérez-Cabal et al., 2006) corrected for milk production.

Although in most PL definitions used throughout time, some authors (i.e., VanRaden and Klaaskate, 1993; Serenius and Stalder, 2004; El-Saied et al., 2005) obtained low estimates of heritability of PL (real and functional) in sheep, rabbits, sows, and in some studies of dairy cows of different countries (i.e., Denmark, Canada, and the United States), the estimates of heritability obtained in the current study indicate that the response to selection for PL can be relatively higher in dairy goats than in the other species mentioned above, and that it is convenient to include PL as an additional criterion in selection indices to improve the genetic progress for longevity in goats.

The standard errors of heritability estimates in this study for milk-production and milk-components (0.02) traits, as for reproduction (0.01 to 0.02) and PL (0.01) traits, were within the range of the estimated values in the studies mentioned above for milk-production (0.001 to 0.07 ), milk-components (0.009 to 0.02$)$, reproduction (0.006 to 0.09$)$, and PL (0.007 to 0.07$)$ traits, indicating that our estimation of parameters is reasonably accurate.

\section{Genetic Correlations}

In goats, the $r_{g}$ estimated by Torrero (2010) between stayability until the second lactation and MY $(0.12 \pm$ $0.05), \mathrm{FY}(0.44 \pm 0.05)$, PY $(0.53 \pm 0.05)$, and FPY $(0.52 \pm 0.05)$ are the only references with respect to the estimation of $\mathrm{r}_{\mathrm{g}}$ between PL and milk-production traits (MY, FY, PY, and FPY) in goats, and although the definition of the variable used as a measure of PL is not the same as the one used in the current study, it would 
be risky to say that one or the other is more valuable for the development of this subject. Both the $r_{g}$ found by Torrero (2010) and the ones obtained in the current study were positive and significant, indicating that it is possible to select indirectly for an increase in PL by selecting for milk-production traits in dairy goats.

The $r_{g}$ estimated between PL72 and MY (0.33 \pm 0.04) was higher than the $r_{g}$ estimated in dairy cows (0.14 to 0.26; Cruickshank et al. 2002; Tsuruta et al., 2004). The $\mathrm{r}_{\mathrm{g}}$ estimated between PL72 and FY (0.23 \pm $0.05)$, and between PL72 and PY $(0.30 \pm 0.05)$, were within the ranges of the $\mathrm{r}_{\mathrm{g}}$ estimated in dairy cows between PL and FY (0.08 to 0.32; Cruickshank et al. 2002; Tsuruta et al., 2005), and between PL and PY (0.22 to 0.35; Cruickshank et al. 2002; Tsuruta et al., 2004). With respect to the milk components, the $r_{g}$ estimated between PL72 and F\% (-0.04 \pm 0.04$)$, and between PL72 and P\% $(-0.002 \pm 0.04)$, were similar to the $\mathrm{r}_{\mathrm{g}}$ estimated in dairy cows between PL and $\mathrm{F} \%$ (-0.08; Kaupe et al., 2007) and between PL and P\% (0.01; Kaupe et al., 2007).

The $\mathrm{r}_{\mathrm{g}}$ estimated between FPL72 and MY (0.39 \pm $0.04)$ was higher than that obtained in cattle $(0.22$; Cruickshank et al., 2002), whereas the $\mathrm{r}_{\mathrm{g}}$ estimated between FPL72 and FY (0.26 \pm 0.05$)$, and between FPL72 and PY $(0.29 \pm 0.06)$ were similar to those obtained in cattle between FPL and FY (0.25; Cruickshank et al., 2002) and between FPL and PY (0.25; Cruickshank et al., 2002). The $\mathrm{r}_{\mathrm{g}}$ found between FPL72 and $\mathrm{F} \%(-0.06$ $\pm 0.05)$, and between FPL72 and P\% (-0.03 \pm 0.04$)$, proved to be lower than the $\mathrm{r}_{\mathrm{g}}$ obtained between FPL and F\% (0.10 \pm 0.11; Samoré et al., 2010) and between FPL and P\% (0.09 \pm 0.11; Samoré et al., 2010) in dairy cows.

The $\mathrm{r}_{\mathrm{g}}$ between KI and PL72 $(0.11 \pm 0.08)$ estimated in the current study was significantly different from the values obtained in sows $(-0.34$ to -0.36 ; Serenius and Stalder, 2004), but similar to the $\mathrm{r}_{\mathrm{g}}$ estimated in Holstein cattle (0.09; Pérez-Cabal and Alenda, 2003). The $\mathrm{r}_{\mathrm{g}}$ between PL72 and the AFK obtained in the current study $(-0.03 \pm 0.06)$, taking into account that it had a large standard error, was similar to that estimated in cattle (-0.11; VanRaden and Klaaskate, 1993) using the same definition of PL as in the present study; however, it was lower than the $r_{g}$ obtained in sheep $(-0.35$ \pm 0.41 ; El-Saied et al., 2005) and sows $(-0.28 \pm 0.11$; Serenius and Stalder, 2004), for which PL was defined as the days from first parturition to culling.

The $r_{g}$ obtained between the milk-production traits (MY, FY, PY, and FPY) and PL72 (0.23-0.33), as with FPL72 (0.26 to 0.39), were higher than the $\mathrm{r}_{\mathrm{g}}$ obtained between the milk components (F\% and P\%) and PL72 $(-0.002$ to -0.04$)$ or FPL72 $(-0.03$ to -0.06$)$, indicating that the indirect genetic improvement of FPL72 and PL72 would be more efficient using the milk-production traits (MY, FY, PY, and FPY) than using the information of the milk components ( $\mathrm{F} \%$ and $\mathrm{P} \%)$. As with $\mathrm{F} \%$ and $\mathrm{P} \%$, it is not advisable to use $\mathrm{KI}$ or AFK as selection criteria to achieve an increase in PL72 and FPL72 because, in addition to the $\mathrm{r}_{\mathrm{g}}$ estimated with PL72 and FPL72 in the KI and the AFK having had high standard errors, the use of KI as indirect selection criterion would result in an $8.1 \%$ decrease in PL72 per generation, whereas if were to decide that the only criterion for selection is AFK, the days of PL72 would increase by only $2.70 \%$ per generation; thus, genetic progress would be slow. However, the optimal strategies for the use of both AFK and KI as indirect selection criteria of PL72 will depend on the economic values to be estimated for these traits.

It is necessary to carry out further research on the adverse relationships observed in this study between longevity and AFK, KI, F\%, and $\mathrm{P} \%$ in dairy goats as well as research the relationship that may exist with other reproductive and disease-resistance traits to obtain correct foundations to know whether these traits may be used in indirect selection for PL in dairy goats.

While waiting for the research on the longevity of goats to advance, the implementation of strategies such as introducing independent culling levels for MY and fat content (Kominakis et al., 2000), including reproductive traits in selection indices (Valencia Posadas et al., 2008) and improving the management of the animals (Montaldo et al., 2010), will lead to improvements in MY, which, in turn, could lead to an indirect increase in PL in goats, due to the genetic relationship between MY and PL, reflected in the values obtained in the present study. In addition to these strategies, the selection of cows with the lowest fat:protein ratio (Buttchereit et al., 2010) and the selection of female sheep with multiple lambings (Abdelqader et al., 2012) have shown that the PL can be increased directly in these species; however, these traits have not been evaluated in goats, so more research on this subject is needed to reach a conclusion about the role they play in selection, to design useful strategies for increasing PL in goats.

\section{Phenotypic Correlations}

The $\mathrm{r}_{\mathrm{p}}$ estimated in this study between PL72 and MY (0.25), FY (0.23), PY (0.25), and FPY (0.25) were positive and significant $(P<0.05)$, similar to the $\mathrm{r}_{\mathrm{p}}$ estimated in goats of the same population by Torrero (2010) between stayability to the second lactation and MY $(0.15 \pm 0.01)$, FY $(0.64 \pm 0.00)$, PY $(0.56 \pm 0.00)$, and FPY $(0.66 \pm 0.00)$, and they were within the $r_{p}$ estimated in dairy cows between PL and FY (0.11 to 0.28; Cruickshank et al., 2002; Ajili et al., 2007) and 
PY (0.17 to 0.29; Cruickshank et al., 2002; VanRaden et al., 2006). The $\mathrm{r}_{\mathrm{p}}$ between PL72 and MY was similar to the $\mathrm{r}_{\mathrm{p}}$ estimated in dairy cows between PL and MY (0.26; Cruickshank et al., 2002).

The estimated $r_{p}$ between FPL72 and MY (0.29 \pm $0.009), F Y(0.26 \pm 0.01)$, and PY $(0.29 \pm 0.01)$ were similar to those obtained in dairy cows between FPL and MY (0.23), FY (0.26), and PY (0.30), defining FPL as the days from birth to culling (Cruickshank et al., 2002), but when FPL was defined as the total days in production (Pérez-Cabal and Alenda, 2003), the $r_{p}$ calculated in the current study were lower than the $r_{p}$ estimated in that population of dairy cows between FPL and MY (0.49), FY (0.47), and PY (0.44).

The estimated $r_{p}$ between KI and PL72 $(-0.01 \pm$ $0.01)$ was similar to that found in sows $(-0.01$; Serenius and Stalder, 2004) but lower than that calculated in cows (0.06; Ajili et al., 2007). In the case of FPL72, the $\mathrm{r}_{\mathrm{p}}$ estimated between KI and FPL72 $(-0.07 \pm 0.01)$ was similar, in terms of its proximity to zero, to that calculated by Pérez-Cabal and Alenda (2003) in Holstein cattle $(-0.04)$. The $r_{p}$ between PL72 and AFK $(-0.08$ $\pm 0.008)$ was similar to that obtained in sheep $(-0.08$ \pm 0.02 ; El-Saied et al., 2005) and sows ( -0.05 ; Serenius and Stalder, 2004), whereas the $\mathrm{r}_{\mathrm{p}}$ between FPL72 and AFK $(-0.08 \pm 0.009)$ was lower than that estimated in Landrace sows (-0.02; Serenius and Stalder, 2004).

The standard errors for $r_{g}$ and $r_{p}$ between PL72 and milk-production traits (0.04 to 0.06 and 0.008 to 0.01 ) were acceptable compared with the value for the parameter and were within the values mentioned for the authors of other studies mentioned above ( 0.05 and 0 to 0.01). However, in the case of the standard errors for $r_{g}$ and $r_{p}$ between PL72 and milk components (0.04 to 0.05 and 0.01 ), or reproduction traits (0.06 to 0.09 and 0.008 to 0.01 ), the standard errors were the same or larger than those for the parameter estimates, meaning that the values of these parameters were probably close to zero or that is necessary to investigate larger data sizes to obtain parameter estimates that are closer to their real values.

\section{Response to Selection}

As has been mentioned throughout this article, knowing the PL of a herd is an aspect of great importance, as it not only helps reduce replacement (Mark, 2004) or health (Rogers et al., 1998) costs, but also, as suggested by the results shown here, when information on PL is available and is included in an index, the selection response is maximized, achieving an increase in simultaneous genetic improvement per generation of 0.15 to $17.35 \%$ for MY, FY, PY, and PL72.
In addition to the inclusion of PL72 in a selection index, the indirect improvement using information of other economically important traits (MY, FY, PY, FPY, F\%, P\%, KI, and AFK) can be also a useful way to increase PL in goats, a goal that, according to the heritability and the $\mathrm{r}_{\mathrm{g}}$ estimated in this study, is relatively easy to achieve, with an even greater response to selection per generation than in other species specialized in milk production.

In research conducted in dairy cows (i.e., Dürr et al., 1999; Cruickshank et al., 2002), the traits that turned out to be (as in the present study) the most relevant for indirect prediction of real and FPL were milkproduction traits. The highest $r_{g}$ in the current study was between MY and PL72 or FPL72, which suggests that using MY as selection criterion is the most viable option for indirect improvement in both FPL72 and PL72, being more effective than any of the other milkproduction traits evaluated in this study. So, if the only selection criterion used were MY, an increase of $39.4 \%$ in the direct response of PL72 would be achieved.

In the present study, we showed some of the advantages gained by using information on PL72 and other traits of economic interest (MY, FY, PY, KI, and AFK) for the direct or indirect selection of PL72; however, the genetic improvement observed in the present study could be more efficient using information on FPL72, because, when removing the effects of voluntary culling (Dekkers, 1993; Mark, 2004), the goat that is able to stay in a herd, in addition to being a good producer, will also be less susceptible to diseases (i.e., mastitis) or reproductive problems (Vukasinovic et al., 1997; Neerhof et al., 2000).

\section{CONCLUSIONS}

The main criteria that determine the culling of a goat from the herd are low MY and FY per lactation, and a low FS. According to the estimates of heritability $(0.22$ and 0.17 for real and FPL, respectively), the genetic improvement of $\mathrm{PL}$ is an achievement that can be made possible by the inclusion of this trait in a selection index, as the improvement is more efficient when the effects of voluntary culling are removed using information on FPL or of other traits commonly evaluated in young goats. The indirect selection for real PL and FPL in dairy goats is more efficient when information on MY, FY, and PY traits is used than when information on reproductive traits, such as AFK or KI, is used. The inclusion of PL in a selection index involving MY, FY, and PY could increase the economic response to selection per generation (0.15 to $17.35 \%)$. However, it is necessary to carry out more research on the economic 
value of the PL of dairy goats to obtain the maximum economic response to selection in this population.

\section{REFERENCES}

Abdelqader, A., A. A. Yacoub, and M. Gauly. 2012. Factors influencing productive longevity of Awassi and Najdi ewes in intensive production systems at arid regions. Small Rumin. Res. 104:37-44.

Ahuya, C. O., J. M. K. Ojango, R. O. Mosi, C. P. Peacock, and A. M. Okeyo. 2009. Performance of Toggenburg dairy goats in smallholder production systems of the eastern highlands of Kenya. Small Rumin. Res. 83:7-13.

Ajili, N., B. Rekik, A. Ben Gara, and R. Bouraoui. 2007. Relationships among milk production, reproductive traits, and herd life for Tunisian Holstein-Friesian cows. Afr. J. Agric. Res. 2:047-051.

Bagnicka, E., E. Wallin, M. Łukaszewicz, and T. Ådnøy. 2007. Heritability for reproduction traits in Polish and Norwegian populations of dairy goat. Small Rumin. Res. 68:256-262.

Barillet, F. 2007. Genetic improvement for dairy production in sheep and goats. Small Rumin. Res. 70:60-75.

Bushara, I., A. M. M. A. Abu Nikhaila, and D. M. Mekki. 2010. Productive and reproductive traits of Taggar goats as affected by type of ration under dry land farming system in western Sudan. Egypt. J. Sheep Goat Sci. 5:209-220.

Buttchereit, N., E. Stamer, W. Junge, and G. Thaller. 2010. Evaluation of five lactation curve models fitted for fat:protein ratio of milk and daily energy balance. J. Dairy Sci. 93:1702-1712.

Caraviello, D. Z., K. A. Weigel, and D. Gianola. 2004. Comparison between a Weibull proportional hazards model and a linear model for predicting the genetic merit of US Jersey sires for daughter longevity. J. Dairy Sci. 87:1469-1476.

Chauhan, V. P. S. 1987. Dairy sire evaluation fitting some of the herdyear-season effects as random. Livest. Prod. Sci. 16:117-130.

Cole, J. B., P. M. VanRaden, and Multi-State Project S-1040. 2010 Net merit as a measure of lifetime profit: 2010 revision. AIPL Research Report NM $\$ 4$ (12-09). Accessed Feb. 22, 2013. http://aipl. arsusda.gov/reference/nmcalc-2010.htm.

Cruickshank, J., K. A. Weigel, M. R. Dentine, and B. W. Kirkpatrick. 2002. Indirect prediction of herd life in Guernsey dairy cattle. J. Dairy Sci. 85:1307-1313.

Dekkers, J. C. M. 1993. Theoretical basis for genetic parameters of herd life and effects on response to selection. J. Dairy Sci. 76:1433-1443.

Dürr, J. W., H. G. Monardes, and R. I. Cue. 1999. Genetic analysis of herd life in Quebec Holsteins using Weibull models. J. Dairy Sci. 82:2503-2513.

El-Saied, U. M., L. F. De La Fuente, J. A. Carriedo, and F. San Primitivo. 2005. Genetic and phenotypic parameter estimates of total and partial lifetime traits for dairy ewes. J. Dairy Sci. 88:3265-3272

Fernández de Sevilla, X., E. Fábrega, J. Tibau, and J. Casellas. 2008 Effect of leg conformation on survivability of Duroc, Landrace, and Large White sows. J. Anim. Sci. 86:2392-2400.

Fletcher, T. D. 2010. Psychometric: Applied Psychometric Theory. $\mathrm{R}$ package version 2.2. Accessed Oct. 10, 2012. http://CRAN.Rproject.org $/$ package $=$ psychometric

García-Peniche, T. B., H. H. Montaldo, M. Valencia-Posadas, G. R. Wiggans, S. M. Hubbard, J. A. Torres-Vázquez, and L. Shepard. 2012. Breed differences over time and estimates of heritability for production and reproduction traits of dairy goats in the United States. J. Dairy Sci. 95:2707-2717.

Gilmour, A. R., B. J. Gogel, B. R. Cullis, and R. Thompson. 2009 ASReml User Guide. Release 3.0. VSN International Ltd., Hemel Hempstead, UK.

Hagiya, K., Y. Atagi, T. Shirai, M. Suzuki, and T. Kawahara. 2005. Prediction of genetic trend for herd life of Holstein cows in Japan. Nihon Chikusan Gakkaiho 76:159-165.

Hatcher, S., K. D. Atkins, and K. J. Thornberry. 2010. Survival of adult sheep is driven by longevity genes. Proc. Assoc. Advmt. Anim. Breed. Genet. 18:580-583.
Jakobsen, J. H., J. W. Dürr, H. Jorjani, F. Forabosco, A. Loberg, and J. Philipsson. 2010. Genotype by environment interactions in international genetic evaluation of dairy bulls. Proc. Assoc. Advmt. Anim. Breed. Genet. 18:133-142.

Jensen, J., I. R. Korsgaard, H. J. Neerhof, A. Vollema, P. Madsen, and V. Ducrocq. 1999. Genetic variation in functional longevity and its relation to mastitis resistance in Danish Holstein. Interbull Bull. 21:161-165.

Kaupe, B., H. Brandt, E.-M. Prinzenberg, and G. Erhardt. 2007. Joint analysis of the influence of $C Y P 11 B 1$ and DGAT1 genetic variation on milk production, somatic cell score, conformation, reproduction, and productive lifespan in German Holstein cattle. J. Anim. Sci. 85:11-21.

Kinghorn, B., and S. Kinghorn. 2009. Pedigree Viewer 6.3. Accessed Aug. 18, 2011. http://www-personal.une.edu.au/ bkinghor/ pedigree.htm.

Kominakis, A., E. Rogdakis, C. Vasiloudis, and O. Liaskos. 2000. Genetic and environmental sources of variation of milk yield of Skopelos dairy goats. Small Rumin. Res. 36:1-5.

Leboeuf, B., J. A. Delgadillo, E. Manfredi, A. Piacère, V. Clément, P. Martin, M. Pellicer, P. Boué, and R. de Cremoux. 2008. Management of goat reproduction and insemination for genetic improvement in France. Reprod. Domest. Anim. 43:379-385.

Mark, T. 2004. Applied genetic evaluations for production and functional traits in dairy cattle. J. Dairy Sci. 87:2641-2652.

Martinez, G. E., R. M. Koch, L. V. Cundiff, K. E. Gregory, and L. D. Van Vleck. 2004. Genetic parameters for six measures of length of productive life and three measures of lifetime production by $6 \mathrm{yr}$ after first calving for Hereford cows. J. Anim. Sci. 82:1912-1918.

Moioli, B., M. D'Andrea, and F. Pilla. 2007. Candidate genes affecting sheep and goat milk quality. Small Rumin. Res. 68:179-192.

Montaldo, H. H., and E. Manfredi. 2002. Organisation of selection programmes for dairy goats. Communication No. 01-35 in Proc. 7th World Congress on Genetics Applied to Livestock Production, Montpellier, France. Institut National de la Recherche Agronomique (INRA), Paris, France.

Montaldo, H. H., M. Valencia-Posadas, G. R. Wiggans, L. Shepard, and J. A. Torres-Vázquez. 2010. Genetic and environmental relationships between milk yield and kidding interval in dairy goats. J. Dairy Sci. 93:370-372.

Mrode, R. A. 2005. Linear Models for the Prediction of Animal Breeding values. 2nd ed. CAB International, Wallingford, UK.

Neerhof, H. J., P. Madsen, V. P. Ducrocq, A. R. Vollema, J. Jensen, and I. R. Korsgaard. 2000. Relationships between mastitis and functional longevity in Danish Black and White dairy cattle estimated using survival analysis. J. Dairy Sci. 83:1064-1071.

Pérez, M. A., D. Hernández, R. Alenda, M. J. Carabaño, and N Charfeddine. 1999. Genetic analysis of true profit for Spanish dairy cattle. Accessed Nov. 13, 2013. https://journal.interbull.org/ index.php/ib/article/view/388.

Pérez-Cabal, M. A., and R. Alenda. 2003. Lifetime profit as an individual trait and prediction of its breeding values in Spanish Holstein cows. J. Dairy Sci. 86:4115-4122.

Pérez-Cabal, M. A. C. García, O. González-Recio, and R. Alenda 2006. Genetic and phenotypic relationships among locomotion type traits, profit, production, longevity, and fertility in Spanish dairy cows. J. Dairy Sci. 89:1776-1783.

Pérez-Razo, M., F. Sánchez, G. Torres-Hernández, C. Becerril-Pérez, J. Gallegos-Sánchez, F. González-Cosío, and C. Meza-Herrera. 2004. Risk factors associated with dairy goats stayability. Livest. Prod. Sci. 89:139-146.

Piles, M., H. Garreau, O. Rafel, C. Larzul, J. Ramon, and V. Ducrocq. 2006. Survival analysis in two lines of rabbits selected for reproductive traits. J. Anim. Sci. 84:1658-1665.

Riggio, V., D. O. Maizon, B. Portolano, H. Bovenhuis, and J. A. M. van Arendonk. 2009. Effect of somatic cell count level on functional longevity in Valle del Belice dairy sheep assessed using survival analysis. J. Dairy Sci. 92:6160-6166.

Rogers, G. W., G. Banos, U. Sander Nielsen, and J. Philipsson. 1998. Genetic correlations among somatic cell scores, productive life, 
and type traits from the United States and udder health measures from Denmark and Sweden. J. Dairy Sci. 81:1445-1453.

Rupp, R., V. Clément, A. Piacere, C. Robert-Granié, and E. Manfredi. 2011. Genetic parameters for milk somatic cell score and relationship with production and udder type traits in dairy Alpine and Saanen primiparous goats. J. Dairy Sci. 94:3629-3634.

Samoré, A. B., R. Rizzi, A. Rossoni, and A. Bagnato. 2010. Genetic parameters for functional longevity, type traits, somatic cell scores, milk flow and production in the Italian Brown Swiss. Ital. J. Anim. Sci. 9(e28):145-152.

Serenius, T., and K. J. Stalder. 2004. Genetics of length of productive life and lifetime prolificacy in the Finnish Landrace and Large White pig populations. J. Anim. Sci. 82:3111-3117.

Sewalem, A., G. J. Kistemaker, V. Ducrocq, and B. J. Van Doormaal. 2005. Genetic analysis of herd life in Canadian dairy cattle on a lactation basis using a Weibull proportional hazards model. J. Dairy Sci. 88:368-375.

Sewalem, A., G. J. Kistemaker, F. Miglior, and B. J. Van Doormaal. 2004. Analysis of the relationship between type traits and functional survival in Canadian Holsteins using a Weibull proportional hazards model. J. Dairy Sci. 87:3938-3946.

Sewalem, A., F. Miglior, G. J. Kistemaker, P. Sullivan, G. Huapaya, and B. J. Van Doormaal. 2007. Modification of genetic evaluation of herd life from a three-trait to a five-trait model in Canadian dairy cattle. J. Dairy Sci. 90:2025-2028.

Short, T. H., and T. J. Lawlor. 1992. Genetic parameters for conformation traits, milk yield and herd life in Holsteins. J. Dairy Sci. 75:1987-1998.

Shrestha, J. N. B., and M. H. Fahmy. 2007. Breeding goats for meat production: 2. Crossbreeding and formation of composite population. Small Rumin. Res. 67:93-112.

Torrero, G. Y. 2010. Estimación de covarianzas para características de longevidad y producción en cabras. MS Thesis. Universidad de Guanajuato, Irapuato, Gto. México.

Torres-Vázquez, J. A., M. Valencia-Posadas, H. Castillo-Juárez, and H. H. Montaldo. 2009. Genetic and phenotypic parameters of milk yield, milk composition and age at first kidding in Saanen goats from Mexico. Livest. Sci. 126:147-153.

Tsuruta, S., I. Misztal, and T. J. Lawlor. 2004. Genetic correlations among production, body size, udder, and productive life traits over time in Holsteins. J. Dairy Sci. 87:1457-1468.

Tsuruta, S., I. Misztal, and T. J. Lawlor. 2005. Changing definition of productive life in US Holsteins: Effect on genetic correlations. J. Dairy Sci. 88:1156-1165.

USDA. 2007. Description of national genetic evaluation systems. Accessed Feb. 29, 2012. http://aipl.arsusda.gov/reference/Form GE_Longevity_1008.pdf.

Valencia, M., J. Dobler, and H. H. Montaldo. 2007. Genetic and phenotypic parameters for lactation traits in a flock of Saanen goats in Mexico. Small Rumin. Res. 68:318-322.
Valencia Posadas, M., H. H. Montaldo Valdenegro, and F. de Jesús Ruíz López. 2008. Parámetros genéticos para características de conformación, habilidad de permanencia y producción de leche en ganado Holstein en México. Técnica Pecuaria en Mexico 46:235248.

Valencia Posadas, M., J. A. Torres-Vázquez, and H. H. Montaldo. 2007a. Evaluación genética para características de producción en cabras del estado de Guanajuato. Pages $155-157$ in Proc. XXII Reunión Nacional sobre Caprinocultura, Zacatecas, Zac. México. Asociación Mexicana de Producción Caprina. Zacatecas, Zac. México.

Valencia Posadas, M., J. A. Torres-Vázquez, and H. H. Montaldo. 2007b. Heredabilidades y repetibilidades para características de producción en cabras lecheras de México. Archivos Latinoamericanos de Producción Animal 15:324. (Abstr.)

Valencia-Posadas, M., Y. Torrero-Garza, C. V. Vicencio-Reyes, L. Shepard, and H. H. Montaldo. 2010. Relaciones fenotípicas entre características de conformación con la habilidad de permanencia a los 36 meses en cabras Alpinas. Acta Universitaria 20:40-44.

Van Bebber, J., N. Reinsch, W. Junge, and E. Kalm. 1997. Accounting for herd, year and season effects in genetic evaluations of dairy cattle: A review. Livest. Prod. Sci. 51:191-203.

Van der Werf, J. 2007. MTINDEX program. Accessed Nov. 3, 2011. http://www-personal.une.edu.au/ jvanderw/software.htm.

VanRaden, P. M., C. M. B. Dematawewa, R. E. Pearson, and M. E. Tooker. 2006. Productive life including all lactations and longer lactations with diminishing credits. J. Dairy Sci. 89:3213-3220.

VanRaden, P. M., and E. J. H. Klaaskate. 1993. Genetic evaluation of length of productive life including predicted longevity of live cows. J. Dairy Sci. 76:2758-2764.

Vicencio, R. C. V. 2009. Correlaciones genéticas entre características de conformación y habilidades de permanencia en cabras lecheras. MS Thesis. Universidad Autónoma de Aguascalientes, Aguascalientes, Ags., México.

Vollema, A. R., S. Van Der Beek, A. G. F. Harbers, and G. De Jong. 2000. Genetic evaluation for longevity of Dutch dairy bulls. J. Dairy Sci. 83:2629-2639.

Vukasinovic, N., J. Moll, and N. Künzi. 1997. Analysis of productive life in Swiss Brown cattle. J. Dairy Sci. 80:2572-2579.

Weppert, M., and J. F. Hayes. 2004. Direct genetic and maternal genetic influences on first lactation production in four breeds of dairy goats. Small Rumin. Res. 52:173-178.

Wiggans, G. R., and S. M. Hubbard. 2001. Genetic evaluation of yield and type traits of dairy goats in the United States. J. Dairy Sci. 84(E. Suppl.):E69-E73. 